\title{
Supercritical extraction of bioactive compounds from cocoa husk: study of the main parameters
}

\author{
Extracción supercrítica de compuestos bioactivos de la cáscara de cacao: estudio de los \\ principales parámetros
}

\author{
Sergio M. Pico Hernández (D) 1, Jaime Jaimes Estévez (D) ${ }^{1}$, Luis J. López Giraldo (D) ${ }^{1 *}$, Cristian J. Murillo Méndez (D) ${ }^{2}$ \\ ${ }^{1}$ Escuela de Ingeniería Química, Universidad Industrial de Santander. Carrera 27 Calle 9. C. P. 680002 . Bucaramanga, Colombia. \\ ${ }^{2}$ Escuela de Química, Universidad Industrial de Santander. Carrera 27 Calle 9. C. P. 680002. Bucaramanga, Colombia.
}

\author{
ARTICLE INFO: \\ Received: February 07, \\ 2018 \\ Accepted: April 08, 2019
}

\section{AVAILABLE ONLINE:}

April 08, 2019

\section{KEYWORDS:}

Supercritical fluids, Carbon dioxide, polyphenols,

natural antioxidants, cocoa

Fluidos supercríticos, dióxido de carbono,

Polifenoles, antioxidantes de origen natural, cascara de cacao

\begin{abstract}
Cocoa is a product of natural origin rich in polyphenols, mainly procyanidins and flavan-3-ols, which has a high antioxidant power. Its regular consumption brings positive health effects. The objective of the present study was to evaluate the effects of diameter of particle, extraction time, temperature, pressure and ethanol concentration in the supercritical fluid extraction (SFE) of bioactive compounds from cocoa husk. This work was developed in two stages. The first stage was aimed to study the impact of the particle size and extraction time. Extractions were carried out under constant conditions. Once particle size and extraction time were defined, it gave way to the second stage, where the effect of three levels of temperature $(308.15,313.15$ and $318.15 \mathrm{~K})$, pressure $(10,15$ and $20 \mathrm{MPa}$ ) and concentration of ethanol $(2,11$, and $20 \%$ ethanol) were evaluated. The results of this study suggest that particle sizes less than $0.26 \mathrm{~mm}$ and extraction times exceeding $147 \mathrm{~min}$ could increase the total polyphenol content (TPC). Finally, a multivariate statistical analysis was developed, showing that the most favorable conditions for obtaining extracts rich in polyphenols corresponded to $308.15 \mathrm{~K}, 20 \mathrm{MPa}$ and $20 \%$ ethanol, under which the TPC was 35.11( \pm 1.57$) E A G m g / L E g$, a total flavan-3-oles content (TFC) of 12.89 $( \pm 0.51) \mathrm{EEPmg} / \mathrm{gLE}$ and total carotenoids content (TCC) of $64.35( \pm 1.54) \mathrm{EBC} \mathrm{mg} / \mathrm{gLE}$. The results obtained suggest that SFE favors the extraction of apolar compounds (carotenoids) from cocoa husk. Likewise, for the optimal extraction point, husk cocoa showed antioxidant capacity of $489.58 \mu \mathrm{mol}$ ET/LEg.
\end{abstract}

RESUMEN: El cacao es un producto rico en polifenoles, principalmente procianidinas y flavan-3-oles, con un gran poder antioxidante. El objetivo del presente trabajo fue estudiar los efectos del diámetro de partícula, tiempo de extracción, temperatura, presión y concentración de etanol en la extracción de compuestos bioactivos de cáscara de cacao utilizando fluidos supercríticos (EFS). Este trabajo se desarrolló en dos etapas. La primera etapa tuvo como objetivo estudiar el impacto del tamaño de partícula y el tiempo de extracción a condiciones constantes. Una vez definidas estas condiciones, se dió paso a la segunda etapa, donde se evaluó el efecto de tres niveles de temperatura $(308.15,313.15$ y $318.15 \mathrm{~K}$ ), presión (10, 15 y $20 \mathrm{MPa}$ ) y concentración de etanol $(2,11$ y $20 \%)$. Los resultados de este estudio sugieren que los tamaños de partícula menores de $0.26 \mathrm{~mm}$ y tiempos de extracción superiores a 147 min podrían aumentar el contenido de polifenoles totales (CPT). Finalmente, se desarrolló un análisis estadístico multivariado, donde se evidenció que las condiciones más favorables corresponden a $308.15 \mathrm{~K}, 20 \mathrm{MPa}$ y $20 \%$ de etanol. Bajo estas condiciones, los rendimientos de CPT, (CTF) y el (CTC) fueron de $35.11( \pm 1.57) \mathrm{mgEAG} / \mathrm{gEL}$, $12.89( \pm 0.51) \mathrm{mgEEP} / \mathrm{gEL}$ y $64.35( \pm 1.54) \mathrm{mg}$ EBC/gEL respectivamente. Del mismo modo, para el punto óptimo de extracción, la cáscara de cacao mostró una capacidad antioxidante de $489.58 \mu \mathrm{mol} \mathrm{ET/gEL}$.

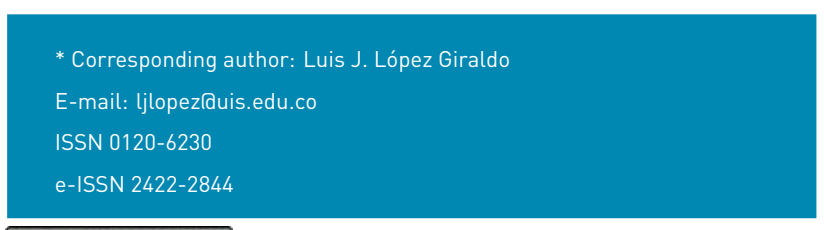

\section{Introduction}

Today, it is possible to identify a crescent interest of consumers for products with a higher nutritional content. 
In that context, the supercritical fluids (SF) are being recognized as potential substitutes for conventional organic solvents for obtaining natural extracts. In this regard, numerous investigations have found that the SF are capable of providing natural extracts with a great bioactivity and quality, excluding any toxicity and responding to safety standards established for food, cosmetic and pharmaceutical industries [1, 2].

Between 2000 and 2013, more than 300 species have been evaluated to obtain extracts using SF to laboratory scale [3]. As an example, in Colombia, there are several studies that evaluate SFE to get products with added value from different vegetable matrices. All these studies are projecting with considerable success the supercritical fluid extraction (SFE) at a national level. However, Colombia has a wide availability of resources that have not been explored. In this sense, it is noted that Colombia is a tropical country with a high potential of production from the primary sector (first generation raw materials), where products such as coffee, palm oil, cotton and cocoa are traditional, and their processing generate elevated volumes of waste (second generation raw materials).

In particular, the cultivation of cocoa in Colombia registers a productivity higher than 47,000 tons per year [4] Also in the world market, this fruit is commercially positioned in third place after sugar and coffee. Under this concept, the Federación Nacional de Cacaoteros (FEDECACAO) between 2002 and 2012 evaluated about 500 trees and from these selected 67 promising clones, among which the CCN-51 is highlighted (collection Castro Naranjal, variety ICS 95 * IMC 67, Ecuadorian origin) as one of the most productive not only in terms of the cocoa fruit but also wastes.

The productive chain of the cocoa in Colombia involves three steps: production, processing and marketing [5]. However, it is noted the absence of alternatives which promote the use of other components (mucilage, shell and husk), most of them being discarded and classified as vegetable waste. Considering that only the $25 \%$ of the total cacao weight is grain, in 2010 FEDECACAO estimated that the national generation of husk could reach a volume of about 30,000 tons [6]. Also at the global level, it is expected that each ton of dry grain will generate 10 tons of husk on wet basis [7]. Some studies mainly in Brazil, Ecuador, Malaysia and Spain have taken advantage of the content of dietary fiber and protein from the husk of cocoa for: i) the formulation of feed for animal consumption [8], ii) recovery of pectins [9] and sugars [10], and iii) the obtaining of adsorbent layers [11] to remove pollutants from water sources. However, the literature has reported limited information about obtaining extracts with nutritional and functional value from cocoa husk using SFE.
A supercritical extraction is defined as a non-conventional process, similar to leaching or solid-liquid extraction and it is characterized by working with solvents at conditions of temperature and pressure higher than their critical point [12]. As a solvent in this type of processes, it is common to use supercritical carbon dioxide $\left(\mathrm{CO}_{2-s c}\right)$. This SF is inert and has a moderate critical point $(\mathrm{Tc}=304.2$ $\mathrm{K}, \mathrm{Pc}=7.38 \mathrm{MPa}$ ). These properties make $\mathrm{CO}_{2-s c}$ an ideal alternative for the processing of compounds with functional and nutraceutical value [13].

It is well known that the final product of any extraction is usually a liquid or solid fraction containing a significant number of compounds. Indeed, an extract is a mixture of all those components contained in an organic matrix (e.g. cocoa husk). It is necessary that those components present affinity with the solvent to reach successfully the extraction [3]. Therefore, the majority of studies related to SFE, tend to focus on defining conditions to obtain extracts with higher content of desired compound.

Nowadays, it is possible to identify a growing interest in obtaining extracts with high content of antioxidants, in particular polyphenols and carotenoids. Recently, it has been shown that cocoa, tea and wine are some foods with a high amount of polyphenols [14]. For this reason, products as cocoa have been recognized as a source of antioxidants due to the presence of polyphenols, especially flavonoids. In this case, flavonoids represent between $12-18 \%$ of cocoa bean polyphenols weight [15], being catechin and epicatechin, the most abundant in this fruit [16].

Regarding to carotenoids, those compounds are precursors of vitamin $A$, with a high antioxidant capacity being responsible of the pigmentation of several organic materials [17]. Since the cocoa bean is a source rich in polyphenols, it can be expected that other constituents of the fruit (husk, shell and mucilage) can be a considerable source of these compounds with an important functional and nutritional value. Among the main factors that must be evaluated in supercritical extraction process, the effect of temperature, pressure, co-solvent concentration, extraction time and particle size are the most prominent [13]. It is important to note that the power of solvation of all SF is influenced by its density; which is identified as a parameter dependent on temperature, pressure and polarity of the SF [18]. Temperature increases reduce the density of the SF, causing a significant reduction in the solubility of some components, which can be reflected as low extraction yields [13]. More regular testing temperatures oscillate between the 303.15 and $383.15 \mathrm{~K}$ [3]. However, when the goal is to extract bioactive compounds, it is necessary to be careful that temperature do not exceed usually the $333.15 \mathrm{~K}$, to avoid thermal degradation [19]. On the other hand, high pressures 
generate significant increases in the density of the SF, improving their power of solvation and promoting the solubilization of the compounds of interest [20]. In most of the studies, the operating pressures vary between 10 and $80 \mathrm{MPa}$ [3]. Since $\mathrm{CO}_{2-s c}$ is one of the most used SF and knowing that it has a relatively low polarity, several studies have introduced the use of co-solvents in order to modify its solvation power and to promote the removal of polar compounds. In that case, the most widely used co-solvent is ethanol (in concentrations of less than 25\%) [21]. This co-solvent has low toxicity, and can be removed easily from extracts, through atmospheric or vacuum evaporation.

Additionally, time and particle size are critical parameters in the extraction process. In this context, it is imperative to work with times of extraction that ensure interaction between the matrix and the SF, and at the same time, allow an adequate saturation of the fluid phase [22]. In this regard, the literature reports times ranging from 4 minutes to 6 hours [13]. In relation to particle size, it is common to experience between 0.10 and $3.0 \mathrm{~mm}$ for cocoa bean [23]. However, it is necessary to define an interval on which the SF could interact with all matrix surface area [24].

Regarding the antioxidant capacity of the polyphenolic compounds, the ORAC method has been widely used in the determination of antioxidant capacity of a lot of fruits and plants, including cocoa beans, for which it has been reported values between 450 to 1477 ET $\mu \mathrm{mol} / \mathrm{g}$ ms $[25,26]$. Notwithstanding the above, literature reports very little information about the antioxidant capacity of the main components of the cocoa fruit lhusk, shell and mucilage). Taking into consideration the above, it is important to evaluate the factors involved in the process, in order to identify favorable conditions for the extraction of these metabolites. Accordingly, the objective of this work was to study and to correlate the influence of the extraction time, particle size, temperature, pressure and mass concentration of ethanol on total contents of polyphenols, flavan-3-ol and carotenoids from cocoa husk clone $\mathrm{CCN}-51$, using $\mathrm{CO}_{2-s c}$ + ethanol as solvents. Besides, it was decided to evaluate the antioxidant capacity of the extract obtained from the most favorable extraction conditions.

\section{Materials and methods}

\subsection{Chemical reagents}

Carbon dioxide (99.9\% v / v) was taken from Linde Colombia SA (Bogota, Colombia). Absolute ethanol (99.9\% v / v), methanol (99.9\% v / v), gallic acid $(99.9 \% \mathrm{w} / \mathrm{w}),(-)$ epicatechin (99.0\% w/w), $\beta$-carotene $(99.9 \% \mathrm{w} / \mathrm{w})$, vanillin
(99.9\% w / w), Folin-Ciocalteu reagent (99.9\% v / v), sodium carbonate $(99.9 \% \mathrm{w} / \mathrm{w}$ ), hydrochloric acid (1.2 N) from Merck (Darmstadt, Germany); and sodium hypochlorite (13\% v / v) from Suquim Ltda. (Bucaramanga, Colombia). Trolox (99.9\% w/ w), and disodium fluorescein AAPH from Sigma-Aldrich (St. Louis, USA).

\subsection{Raw material and chemical characterization}

\section{Raw material collecting}

60 cocoa fruits of CCN-51 clone, were selected. Cocoa was collected from three farms in different regions of the department of Santander, Colombia: La Victoria (Rionegro, average height: 708 masl, average Temp: $298.15 \mathrm{~K}$ ), Villa Monica (San Vicente de Chucurí, average height: 693 masl, average Temp: $300.15 \mathrm{KJ}$ and Lebrija (Lebrija, average height: 1086 masl, average Temp: $297.15 \mathrm{KJ}$. All fruits were collected from different trees, taking care to select those that had similar characteristics laverage length of 22.13 $\mathrm{cm}$, average diameter $9.26 \mathrm{~cm}$, average weight of 965.28 g) and a homogeneous physiological maturity (24 weeks).

\section{Preteatment of cocoa husk}

Briefly, cocoa husk was washed and disinfected, using a sodium hypochlorite solution $10.05 \%$ v / v) latter, cocoa beans, pulp and mucilage were removed from husk manually. The husk recovered was subjected to a cutting process (pieces of about $2.00 \pm 0.50 \mathrm{~cm}^{3}$ ) to reduce its size. Next, a heat treatment was applied to avoid possible oxidation and to inhibit the action of polyphenol oxidase enzyme [26]. In the first step of inhibition, approximately $1000 \mathrm{~g}$ of cocoa husk pieces placed in contact with 2000 $\mathrm{cm}^{3}$ of water at $368.15( \pm 3.15) \mathrm{K}$ in an enzymatic reactor for $5 \mathrm{~min}$. In the second stage, the pieces were immersed in cold water to 274.15 ( \pm 4.15) $\mathrm{K}$ for $20 \mathrm{~min}$ [27]. Drying was carried out at 323.15 ( \pm 3 ) $\mathrm{K}$ using a stove with air recirculation system for 26 hours, where the material reached constant weight. Finally, the size of the material was reduced using a mill to reach a particle size of 0.258 $\mathrm{mm}$.

\section{Cocoa husk characterization}

- Physical Characterization: The physical characterization was based on the determination of average particle diameter using the method of the American Society of Association Executives (ASAE, 1996).

- Chemical Characterization: The chemical characterization involved: i) assessment of moisture, ash, fat, fiber, protein and carbohydrates present in the material, using the methods 966.02; 923.03; 
920.39; 920.87 and 962.09 of Official Analytical Chemists Association (18th Ed. AOAC, 1996), respectively. The extraction of polyphenols and flavan-3-ols was developed using the methodology developed in the research group [28]. The carotenoids content was measured using spectrophotometric techniques [29].

\subsection{Analytical method}

\section{Determination of particle size and extraction time for polyphenol extraction}

The influence of particle size (Ps) and extraction time $\left(t_{\text {ext }}\right)$ on the TPC, was evaluated using the factorial design center point $+2^{2}+$ axial points centered on the faces, and it was analyzed using the response surface methodology [13, 23]. Three levels of particle size and extraction time were selected: mesh $-50 /+100$ ( $0.223 \mathrm{~mm}$ ), mesh $-16 /+40$ ( $0.677 \mathrm{~mm}$ ) and mesh -8/+14 ( $1.785 \mathrm{~mm}$ ); and 40, 120 and $200 \mathrm{~min}$, respectively. The design was carried out at constant conditions of temperature (308.15 K), pressure (10 MPa) and mass concentration of ethanol ( $11 \%$ ethanol).

\section{Extraction profiles of total polyphenols, flavan-3-ols and carotenoids}

The behavior of the extraction profiles was evaluated in function of pressure, temperature and mass concentration of ethanol. Supercritical extractions were performed using a supercritical fluids lab unit (Figure 1) designed and built by the Instituto de Biotecnología y Agroindustria (IBA) of the Universidad Nacional de Colombia [30]. Briefly, a sample of $60.0 \mathrm{~g}$ of cocoa husk was placed into a $250 \mathrm{~cm}^{3}$ cylinder extractor. Ethanol was added manually $(2,11$ and $20 \% \mathrm{w} / \mathrm{w}$ ) over the mass of extraction. Then, the system was pressurized with carbon dioxide (up to 10, 15 and 20 MPa) using an air pump (Milton-Roy Williams, CP250V225 model). Cylinder temperature (308.15; 313.15 and 318.15 $\mathrm{KJ}$ was regulated using an isothermal water bath with air bubbling. After this time, the system was depressurized and the extract was stored in a collector cylinder, equipped with ethanol, which worked as a solute trap. Finally, the extracts were collected in ambar vials, and storaged under darkness conditions at $276.15 \mathrm{~K}$.

\section{Chemical characterization of the collected extracts}

The overall performance of each extraction was determined gravimetrically. The collected extracts were concentrated by vacuum evaporation $(323.15 \mathrm{~K}$ and $0.01 \mathrm{MPa}$ ) and lyophilized (233.15 $\mathrm{K}$ and $0.013 \mathrm{MPa}$ ). Equation (1) was used to determine the extraction yield. It expresses the results as a percentage of lyophilized extract as gram per gram of cocoa husk dry basis /g LE/g db.).

$$
\% \text { yield }=\left(\frac{\text { m.lyophilized }}{\text { m.huskloaded }}\right) * 100 \%
$$

- Total polyphenol content determination: In order to determine the TPC, $50 \mu$ l of sample was mixed with 1.5 $\mathrm{ml}$ of Folin Ciocalteu reagent (10\% v/v) and incubated for $5 \mathrm{~min}$ under conditions of darkness. Then, 1.5 $\mathrm{ml}$ of a sodium carbonate solution $(7.5 \% \mathrm{w} / \mathrm{v})$ and the final mixture obtained were mixed and allowed for 60 minutes. The absorbance of samples was measured at $765 \mathrm{~nm}$ using distilled water as the blank. Finally, the TPC was determined using gallic acid as reference and expressed as milligrams of gallic acid equivalents per gram of lyophilized extract (EAG mg/g LE) [31].

- Content of flavan-3-ols total (TFC) determination: TFC was determined using the vanillin- $\mathrm{HCl}$ assay. 500 $\mu \mathrm{l}$ of the extract was mixed with $1250 \mu \mathrm{l}$ assess vanillin (1\% $\mathrm{w} / \mathrm{v}$, prepared daily in methanol) and $1250 \mu \mathrm{l}$ of $9 \mathrm{M} \mathrm{HCl}$ in methanol. The mixture was incubated for $20 \mathrm{~min}$ at $303.15 \mathrm{~K}$ under darkness conditions. For each case, two blanks were prepared: i) replacing vanillin sample volume $(1 \% \mathrm{w} / \mathrm{v})$, and ii) replacing the methanol solution of vanillin. The final absorbance was determined at $500 \mathrm{~nm}$ subtracting the absorbance of the two blank. The TFC is calculated from a calibration curve constructed with (-)- epicatechin as standard and the results expressed in milligrams of epicatechin equivalents per gram of lyophilized extract (mg EP/g EL) [32].

- Total carotenoid content (TCC): Total carotenoid quantification was performed building a calibration curve of $\beta$-carotene using a spectrophotometer reading at $450 \mathrm{~nm}$ with ethanol as blank. Results were expressed in equivalent milligrams of $\beta$-carotene per gram of lyophilized extract (EBC mg / g) [33].

- Determination of antioxidant capacity: The antioxidant capacity was evaluated with the hydrophilic ORAC. Briefly, $150 \mu \mathrm{L}$ of fluorescein (FL) and $25 \mu \mathrm{l}$ of the solution to evaluate lextract, standard or blankl were placed in the wells of a microplate with 96 dark places. The microplate was incubated at $310.15 \mathrm{~K}$ for $10 \mathrm{~min}$ and then, to each well $25 \mu \mathrm{L}$ of AAPH were added. The fluorescence signal was evaluated $1 \mathrm{~min}$ each during $1 \mathrm{~h}$ under wavelengths of excitation and emission of 485 and $530 \mathrm{~nm}$, respectively. Quantification was performed using a calibration curve with Trolox as standard, and the results are expressed in micromol of Trolox equivalents per gram of lyophilized extract $(\mu \mathrm{mol}$ TE/g LE) [34]. 


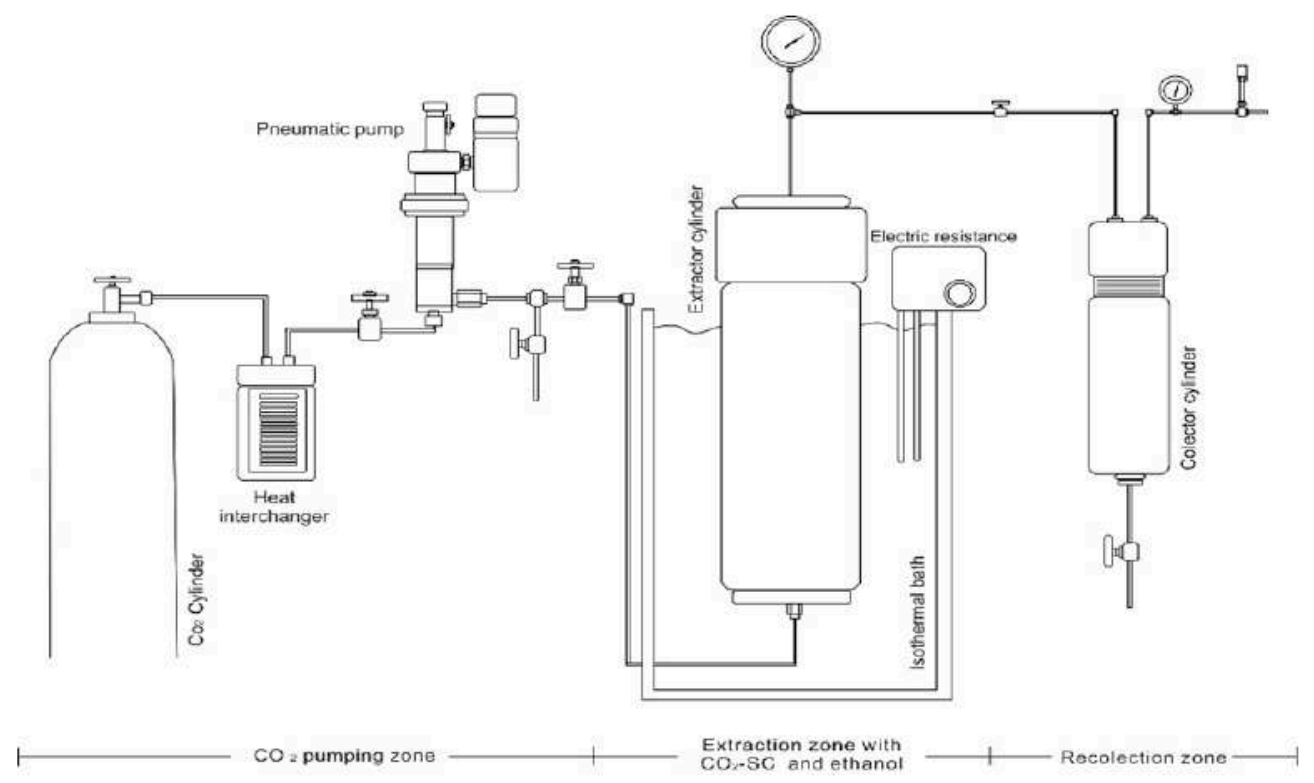

Figure 1 Experimental setup of the supercritical fluids unit

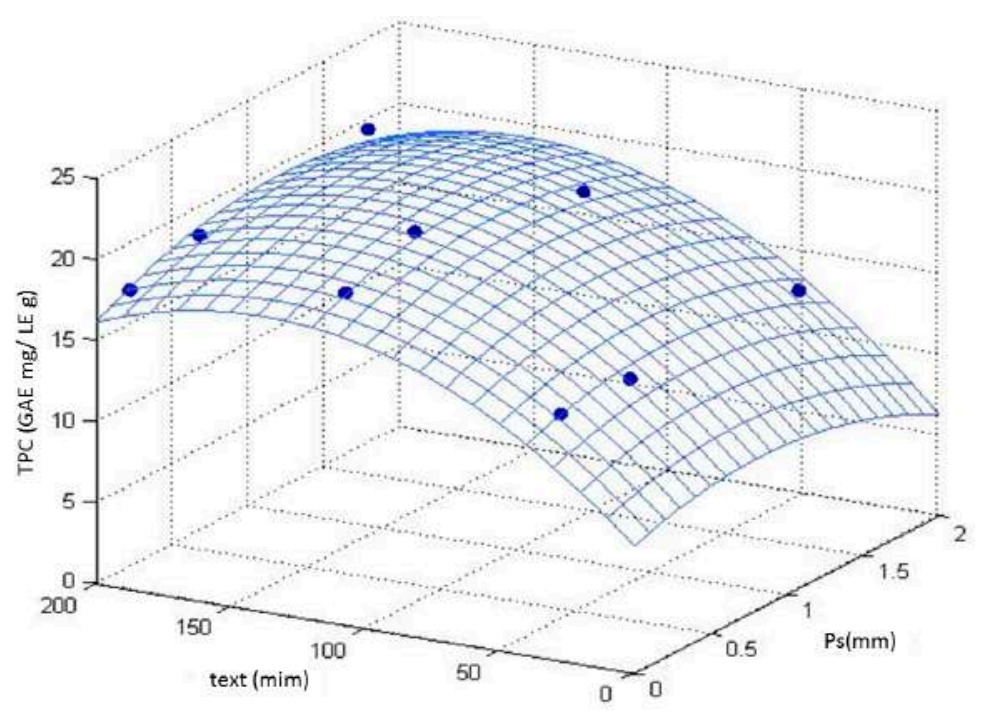

Figure 2 Response surface for TPC as function of particle size and extraction time. The results were obtained at $308.15 \mathrm{~K}, 10 \mathrm{MPa}$ and $X=11 \%$

\section{Mathematical correlation of variables involved in the process of extraction}

To describe mathematically the process of supercritical extraction for cocoa husk, a generic model is proposed in terms of each family of compounds (polyphenols, flavan-3-ols as well as total carotenoids) and efficiency. The dependent variables TPC, TFC, TCC and \% Yield, and independent variables temperature $(T)$, pressure $(P)$ and mass concentration of ethanol (X) were correlated by implementing multiple regression matrix [35]. In all cases, both considered as quadratic nonlinear interaction of the independent variables $(T, P, X, T * P, P * X, T * X$, $P^{2}, T^{2}, X^{2}$ ). The Calculation algorithm was programmed in MATLAB R2018b and the degree of adjustment of the proposed mathematical models were evaluated by calculating the average absolute relative deviation (AARD) expressed in the Equation (2)

$$
A A R D(\%)=\frac{100}{n} \sum\left(\frac{C . \exp \text { erimental }- \text { C.calculated }}{\text { C. exp erimental }}\right)
$$

$n$ is the number of data, $c_{e}$ xperimental and $c_{c}$ alculated correspond to the experimental and the model estimated value, respectively. The best regression is based on minimizing the error between the experimental value and the theoretical value obtaining values close to zero. 


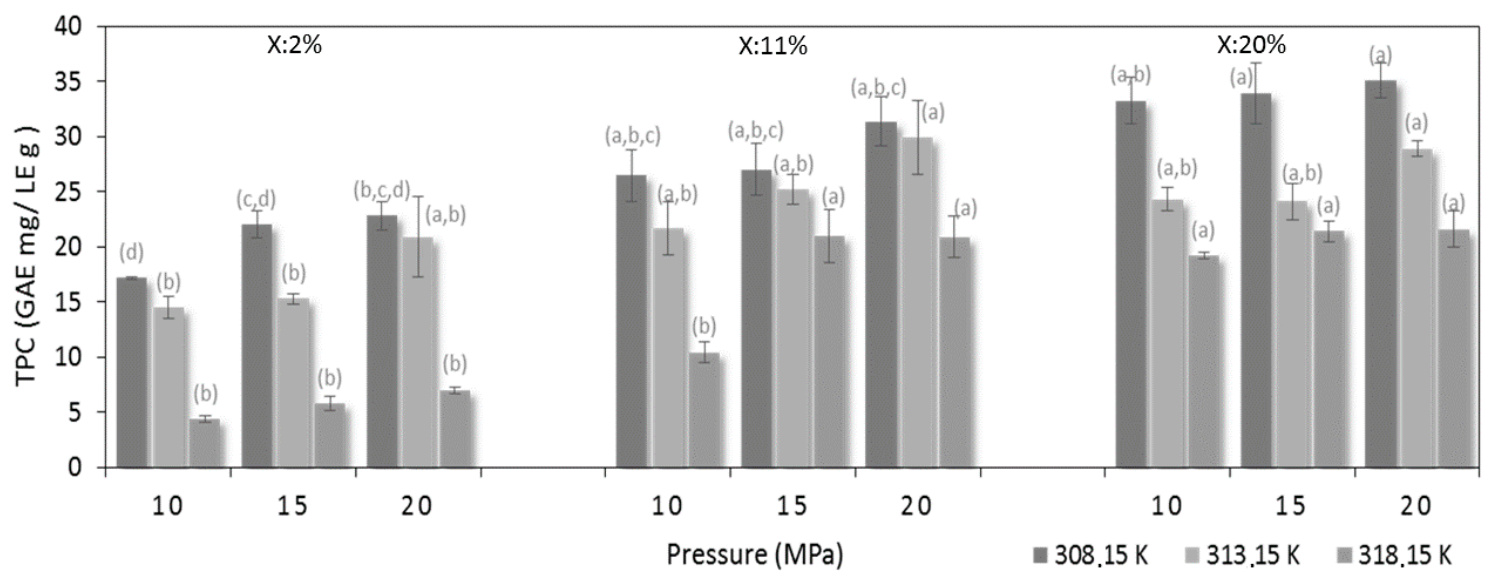

Figure 3 Variation of the total polyphenol content extracted as function of temperature pressure and mass concentration of ethanol

a)

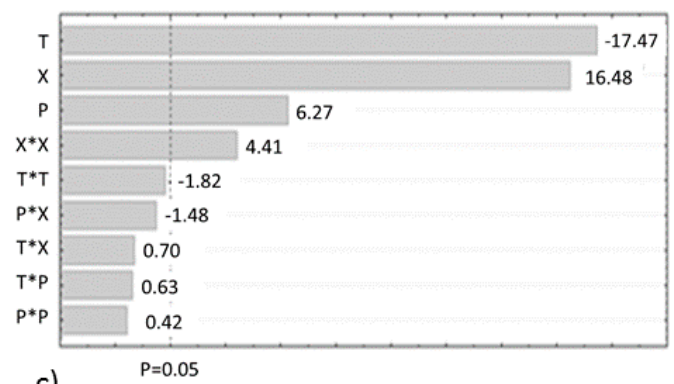

c)

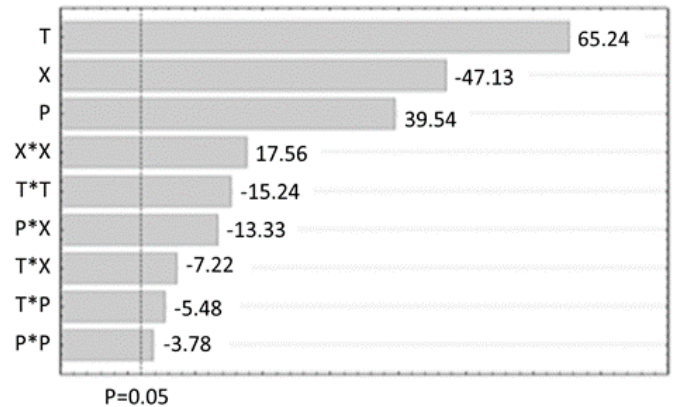

b)
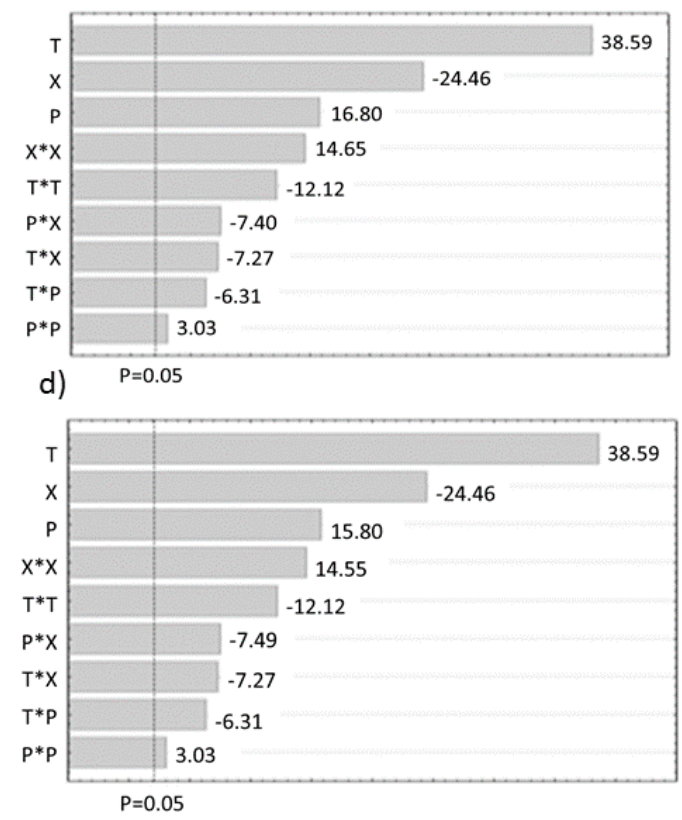

Figure 4 Pareto diagrams for TPC (a). TFC (b). TCC (c) and yield (d)

\section{Statistical analysis}

The influence of extraction time, particle size, temperature, pressure and mass concentration of ethanol was evaluated by variance analysis. The main effects plots, Pareto diagrams, Tukey HSD tests and other statistical analyzes were performed using Statistica7, developed by StatSoft Inc., on trial for Windows 7. The response surfaces were simulated using Matlab R2018b, MathWorks ${ }^{\circledR}$ developed.

\section{Results and discussion}

\subsection{Characterization of Cocoa Husk}

The profile of components quantity during the characterization of the for cocoa husk clone CCN-51 is summarized in the Table 1. The values of moisture, fat, protein, ash, fiber and carbohydrates were similar to those reported for other authors [8], that characterizes the husk of a Brazilian clone, with some differences, which could be attributed to several factors, as agronomic and environmental conditions and the physiological and genetic diversity [36]. 
a)
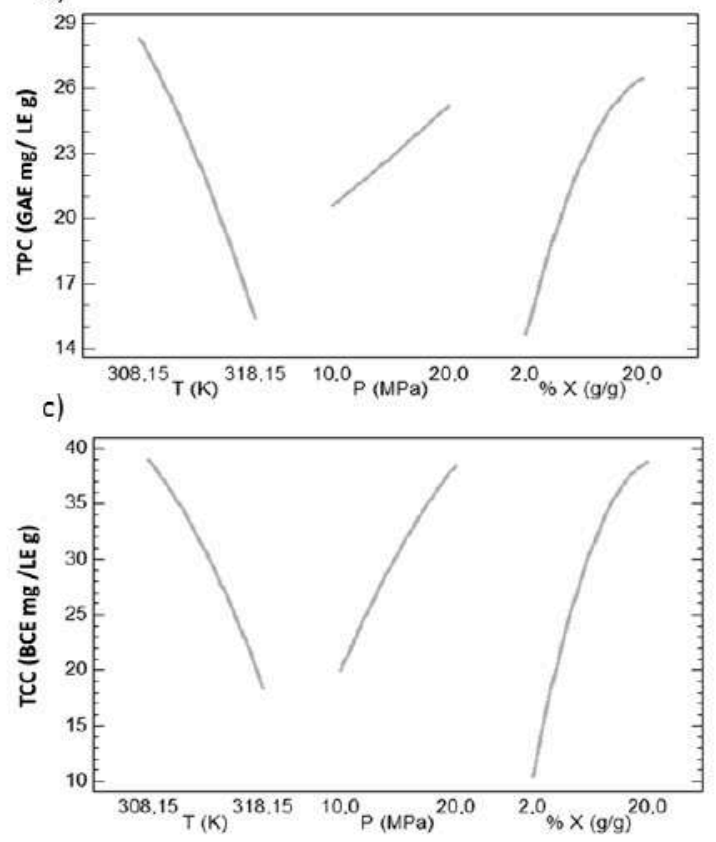

b)
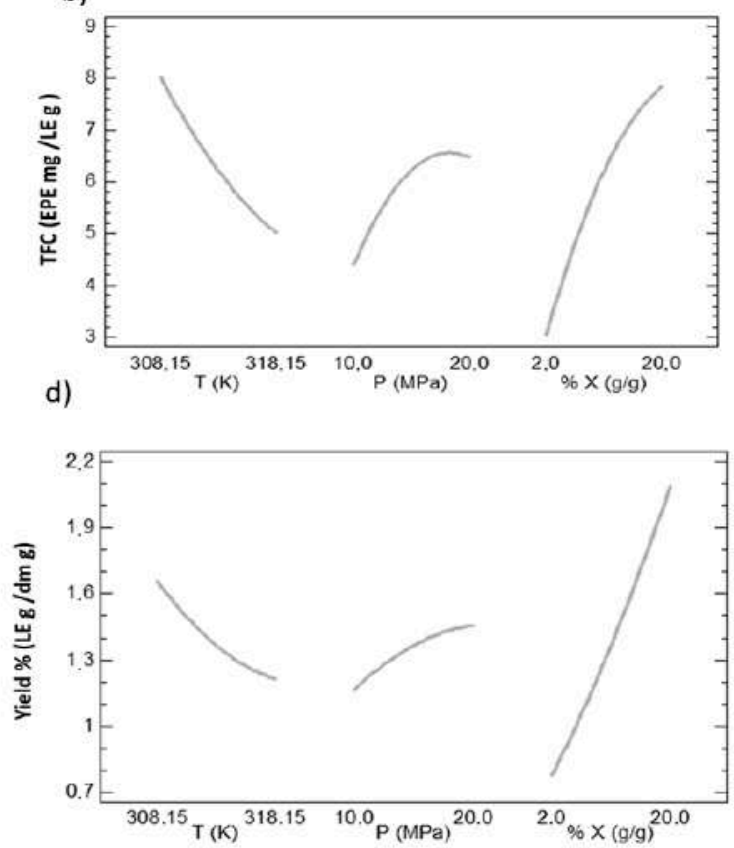

Figure 5 Graphics of principal effects on TPC (a). TFC (b). TCC (c) and yield (d)

Table 1 Composition of cocoa husk (clon CCN-51)

\begin{tabular}{lcc}
\hline Component & $\begin{array}{c}\text { Content This work } \\
\text { (g/100 g db)* }\end{array}$ & $\begin{array}{c}\text { Content Vriesmann et al. } \\
\text { (2011) }\end{array}$ \\
\hline Moisture & $4.56 \pm 0.30$ & $8.50 \pm 0.06$ \\
Fat & $0.25 \pm 0.01$ & $1.50 \pm 0.13$ \\
Protein & $5.99 \pm 0.05$ & $8.60 \pm 0.09$ \\
Ash & $7.76 \pm 0.01$ & $6.70 \pm 0.02$ \\
Fiber & $28.13 \pm 0.10$ & $36.60 \pm 0.01$ \\
Carbohydrates & $81.44 \pm 0.28$ & $61.90 \pm 1.8$ \\
calories value (kcal/100 g) & 351.97 & 295.5 \\
\hline Component & \multicolumn{2}{c}{ Content (db/gdb)* } \\
\hline TPC (mg EAG/g db) & \multicolumn{2}{c}{$32.738 \pm 1.332$} \\
TFC (mg EEP/g db) & \multicolumn{2}{c}{$21.377 \pm 0.598$} \\
TCC (mg EBC/g db) & \multicolumn{2}{c}{$0.077 \pm 0.005$} \\
\hline
\end{tabular}

* The results are expressed in terms of average and standard deviation for $n=2$

Related to the total polyphenol content (TPC), the value determined in this work was 1.56 times greater than reported in Ecuador [37] and 1.22 times lower than that quantified for husks of Brazilian clones [7]. Additionally, the TPC for cocoa husk obtained in this work ( $32.738 \mathrm{mg}$ EAG/g db) was 3.53, 2.60 and 1.34 times higher than reported for the banana husk, avocado and passion fruit, respectively [38]. These results suggest that cocoa husk (agro-industrial waste), can be used as a source to obtain polyphenols. In the literature, there are not reports including contents of flavan-3-ols (TFC) and total carotenoids (TCC) for husk cocoa extracts. The values presented in Table 1 show that the TFC and TCC are of $21.377 \mathrm{mg} \mathrm{EEP/g} \mathrm{db}$ and $0.077 \mathrm{mg} \mathrm{EBC} / \mathrm{g} \mathrm{db}$, respectively.

\subsection{Analysis of particle size and extraction time on total polyphenols content from cocoa husk}

To determine the particle size (Ps) and extraction time $\left(t_{\text {ext }}\right)$ favorable to obtaining extracts rich in polyphenols using SCF, a surface response methodology (SRM) was implemented. The experimental data obtained (supplement data) were fitted to the second order expression which present in Equation (3).

$$
\begin{array}{r}
T P C=\alpha 0+\alpha 1 * t . e x t+\alpha 2 * P . s+\alpha 3 *(\text { t.ext }) 2 \\
+\alpha 4 *(P . s) 2+\alpha 5 * \text { P.s } * \text { t.ext }
\end{array}
$$

In this expression, the relationship between the TPC and the linear and quadratic effect of the two independent variables 
Table 2 Regression coefficients estimated from a second-order model

\begin{tabular}{|c|c|c|c|}
\hline Factor & \multicolumn{2}{|c|}{ Coefficients } & Value-p \\
\hline Intercept & $\alpha_{0}$ & 7.85873 & $0.000176^{*}$ \\
\hline$t_{\text {ext }}$ & $\alpha_{1}$ & 0.14934 & $0.000015^{*}$ \\
\hline Ps & $\alpha_{2}$ & 3.59479 & 0.191365 \\
\hline$t_{\text {ext }} * t_{\text {ext }}$ & $\alpha_{3}$ & -0.00054 & $0.000033^{*}$ \\
\hline Ps*Ps & $\alpha_{4}$ & -2.19857 & $0.078260 * *$ \\
\hline$P s * t_{\text {ext }}$ & $\alpha_{5}$ & 0.00859 & 0.235957 \\
\hline Unadjusted & & & 0.127206 \\
\hline $\mathbf{R}^{2}$ & & 0.82 & \\
\hline
\end{tabular}

Table 3 Experimental data of particle size and extraction time

\begin{tabular}{ccc}
\hline $\begin{array}{c}\text { Ps (mm) } \\
\text { (Average) }\end{array}$ & $\begin{array}{c}\text { Ext.t. } \\
\text { (min) }\end{array}$ & $\begin{array}{c}\text { TPC } \\
\text { (mg EAG/gEL) }\end{array}$ \\
\hline $0.223^{(a)}$ & $200^{(a)}$ & 16.84 \\
$0.223^{(a)}$ & $200^{(a)}$ & 17.22 \\
$0.223^{(a)}$ & $120^{(a)}$ & 17.73 \\
$0.223^{(a)}$ & $120^{(a)}$ & 20.38 \\
$0.223^{(a)}$ & $40^{(b)}$ & 14.82 \\
$0.223^{(a)}$ & $40^{(b)}$ & 12.76 \\
$0.677^{(a)}$ & $120^{(a)}$ & 20.34 \\
$0.677^{(a)}$ & $120^{(a)}$ & 21.59 \\
$0.677^{(a)}$ & $40^{(b)}$ & 13.84 \\
$0.677^{(a)}$ & $40^{(b)}$ & 13.65 \\
$0.677^{(a)}$ & $200^{(a)}$ & 17.92 \\
$0.677^{(a)}$ & $200^{(a)}$ & 18.45 \\
$1.785^{(a)}$ & $40^{(b)}$ & 13.12 \\
$1.785^{(a)}$ & $40^{(b)}$ & 14.50 \\
$1.785^{(a)}$ & $200^{(a)}$ & 18.98 \\
$1.785^{(a)}$ & $200^{(a)}$ & 19.70 \\
$1.785^{(a)}$ & $120^{(a)}$ & 18.59 \\
$1.785^{(a)}$ & $120^{(a)}$ & 16.82 \\
$0.677^{(a)}$ & $120^{(a)}$ & 19.89 \\
$0.677^{(a)}$ & $120^{(a)}$ & 23.17 \\
$0.677^{(a)}$ & $120^{(a)}$ & 18.88 \\
$0.677^{a}$ & $120^{a}$ & 19.75 \\
\hline
\end{tabular}

For each line. "Means that have no superscript in common are significantly different from each other" (Tukey's HSD)

(Ps and text) is considered. The Table 2 shows the estimated regression coefficients.

The results of statistical analysis using a confidence interval of 95\% shows that lineal effect of $t_{\text {ext }}\left(\alpha_{1}\right)$ and quadratic effect of text $\left(\alpha_{3}\right)$ are significant on response variable TPC. However, the
Table $4 \mathrm{p}$-value for TPC, TCC and TFC

\begin{tabular}{cccc}
\hline $\begin{array}{c}\text { Independent } \\
\text { Factor }\end{array}$ & $\begin{array}{c}\text { TPC } \\
\text { p-value }\end{array}$ & $\begin{array}{c}\text { TCC } \\
\text { p-value }\end{array}$ & $\begin{array}{c}\text { TFC } \\
\text { p-value }\end{array}$ \\
\hline $\mathrm{T}(\mathrm{K})$ & 0.000000 & 0.000001 & 0.000001 \\
$\mathrm{P}(\mathrm{MPa})$ & 0.000094 & 0.000032 & 0.000032 \\
$\mathrm{X}(\%)$ & 0.000000 & 0.000000 & 0.000000 \\
\hline
\end{tabular}

results presented by of other researchers [13] show that the extraction time, size and morphology of the solid material have a direct effect on the amount of recovered extract. Therefore, in this work the confidence interval was modified to $90 \%$ to consider the effect of Ps on response variable TPC. Under this consideration, the quadratic effect of Ps $\left(\alpha_{4}\right)$ was included into the fitted equation (Equation (4)).

$$
\begin{array}{r}
T P C=7.85873+0.14934 * \text { t.ext } \\
-0.00054 *(\text { t.ext }) 2-2.19857 * \text { P.s } 2
\end{array}
$$

The Equation (4) represents in $80.35 \%$ the behavior of the experimental data reported in the Figure 2 that shows the response surface obtained. Additionally, a routine programmed in Matlab R2018b was used to determine the maximum of Equation (3). The conditions for $P s$ and $t_{\text {ext }}$ that allows obtaining the maximal TPC were $1.105 \mathrm{~mm}$ and $147.18 \mathrm{~min}$, respectively. However, it is important to underline that according to Tukey HSD test (Table 3), $t_{\text {ext }}$ and Ps have no significant effect on TPC after 120 min of extraction and for values less than 1.105 $\mathrm{mm}$, respectively. Regarding to $\mathrm{Ps}$, authors observed that $\mathrm{Ps}$ must be near $0.25 \mathrm{~mm}$ for different organic matrices [39, 40]. Therefore, for the subsequent analysis the text and Ps was fixed at $140 \mathrm{~min}$ and $0.26 \mathrm{~mm}$, respectively. These values are considered enough to ensure adequate saturation of the fluid phase $\left(\mathrm{CO}_{2}-s c+\right.$ ethanol $)$ and to facilitate the production of extracts rich in polyphenolic compounds from cocoa husk.

\subsection{Analysis of temperature. pressure and co-solvent concentration on profiles of total polyphenols. flavan-3-ols and carotenoids}

Figure 3 shows the TPC as function of independent variables evaluated ( $T, P$ and $X$ ). Error bars indicate the variation obtained in at least four measurements for TCP values. According to Tukey HSD test, the values with different letter show significant differences of $95 \%$ between average values determined for each experimental point.

The ANOVA analysis present in the Table 4 shows that for the experimental conditions tested. the three independent factors (T. P and $X$ ) generate significant effects on the TPC, TFC and TCC (p-value $<0.05$ ).

This can be confirmed graphically through Pareto diagrams presented in Figure 4. From this figure it can be concluded that the temperature is a factor with significant influence and also generates decreases on response variables. Additionally, the linear and quadratic effects of pressure and mass concentration 
Table 5 Comparison of yield obtained from different matrices

\begin{tabular}{cccc}
\hline Matrix & Experimental conditions & $\begin{array}{c}\text { Yield \%* } \\
\text { (E g /dm g) }\end{array}$ & Reference \\
\hline $\begin{array}{c}\text { Theobroma cacao L. } \\
\text { (Cocoa Husk) }\end{array}$ & 308.15 K. 20 MPa y 20\% of ethanol & $2.3_{(}(c)$ & This work \\
\hline $\begin{array}{c}\text { Coffea canephora } \\
\text { (Coffe husk) }\end{array}$ & 323.14 K. 20 MPa y 8\% of ethanol & $2.2_{(}(c . d)$ & P. Costa et al.[41] \\
\hline $\begin{array}{c}\text { Persea grattissima } \\
\text { lavocado bagasse) }\end{array}$ & 333 K. 30.4 MPa y 0\% of ethanol & $6.8_{(}(a)$ & Döker et al. 2014 [44] \\
\hline $\begin{array}{c}\text { Mangifera indica L. } \\
\text { (Mango skin) }\end{array}$ & 313.15 K. 30 MPa y 0 \% of ethanol & $1.7_{(d)}$ & García et al.[45] \\
\hline $\begin{array}{c}\text { Bactris gasipaes } \\
\text { (chontaduro pulp)) }\end{array}$ & 313.15 K.30 MPa y 0\% of ethanol & $4.1(b)$ & Espinosa-Pardo et al. 2014 [43] \\
\hline
\end{tabular}

Different letters indicate significative differences $(p<0.05)$

Table 6 Parameters and AARD of the models empirics

\begin{tabular}{|c|c|c|c|c|c|c|c|c|c|c|c|}
\hline \multicolumn{11}{|c|}{ Dependet varible $=\beta_{0}+\beta_{1} T_{e x t}+\beta_{2} P+\beta_{3} X+\beta_{4} T_{e x t} P+\beta_{5} P X+\beta_{6} T_{e x t} X+\beta_{7} P^{2}+\beta_{\mathrm{g}} T_{e x t}^{2}+\beta_{9} X^{2}$} & \multirow{3}{*}{ AARD $(\%)$} \\
\hline \multicolumn{11}{|c|}{ Parameters } & \\
\hline & $\beta_{0}$ & $\beta_{1}$ & $\beta_{2}$ & $\beta_{3}$ & $\beta_{4}$ & $\beta_{5}$ & $\beta_{6}$ & $\beta_{7}$ & $\beta_{8}$ & $\beta_{9}$ & \\
\hline TPC & -4065 & 27.557 & -3.338 & -0.489 & -0.0118 & -0.0154 & 0.0070 & 0.0106 & -0.0465 & -0.0359 & $9.30 \%$ \\
\hline TFC & 1196 & -7.876 & 7.022 & 6.4309 & -0.0197 & 0.0251 & -0.0202 & -0.0304 & 0.0129 & -0.0102 & $12.20 \%$ \\
\hline TCC & -8262 & 52.056 & 48.284 & 14.811 & -01467 & 0.1065 & -0.0423 & -0.0556 & -0.0822 & -0.0727 & $10.33 \%$ \\
\hline Yield & 184 & -1.128 & 0.279 & -0.603 & -0.0005 & -0.0006 & 0.0021 & -0.0035 & 0.0017 & 0.0014 & $5.36 \%$ \\
\hline
\end{tabular}

of ethanol generates a significant increases on the response variable.

The main effects diagrams (Figure 5) were analyzed. As can be observed. the most pronounced changes occur with decreasing temperature and increasing the mass concentration of ethanol. producing increments until 53.84; 37.5; 25.0 and $31.8 \%$ for the TPC, TFC, TCC and yield. respectively.

The behavior described in Figure 5 is consistent with that observed in other works [41-43], who made supercritical extraction from coffee husk, peach seeds and chontaduro pulp, respectively. In general, the results obtained in this study are particularly interesting because despite the existence of a polarity modifier (in this case ethanol). The apolar contribution of $\mathrm{CO}_{2}$-sc have a solvation power of the fluid phase. Therefore, this extraction technique allows the production of extracts rich in polar (polyphenols and flavan-3-ols) and nonpolar (carotenoids) compounds from cocoa husk.

In the range studied in this work, the most favorable conditions to obtain extracts rich in polyphenols corresponded to $308.15 \mathrm{~K}$, $20 \mathrm{MPa}$ and $20 \%$ ethanol. Where the TPC was 35.11 ( \pm 1.57$) \mathrm{GAE}$ $\mathrm{mg} / \mathrm{LE} \mathrm{g}$. Also, for these conditions extracts showed to have a TFC and TCC $12.89( \pm 0.51)$ EPE $\mathrm{mg} / \mathrm{LE} \mathrm{g}$ and BCE $64.35( \pm 1.54)$ $\mathrm{mg} / \mathrm{LE} \mathrm{g}$, respectively. Finally, the maximum TPC of this work is similar to that reported by Costa et al. [41] who obtained 36 $( \pm 1) \mathrm{GAE} \mathrm{mg} / \mathrm{LE} \mathrm{g}$ from coffee husk working at $323.14 \mathrm{~K} .20 \mathrm{MPa}$ and $8 \%$ ethanol. The maximum yield obtained was $2.3 \%$ which is considered according to typical values obtained by several authors in different organic wastes (Table 5).

\subsection{Correlation of variables involved in supercritical extraction}

Table 6 shows the parameters and AARD (\%) of the models proposed to describe the behavior of each of the dependent variables (TPC. TFC. TCC and yield) involved in the supercritical extraction from cocoa husk (clone $\mathrm{CCN}-51$ ).

From the overall comparison of the values of AARD, it can be inferred that the proposed models are able to describe the global trend of the experimental data with values that do not exceed a AARD of $12.2 \%$. At the time of predicting the behavior of extraction with SCF, it is common to work with values that are found in an interval of $1 \%$ to $30 \%$ of AARD [46]. Since, small changes in the independent variables bring big changes in the power of Solvation of the SCF.

\subsection{Antioxidant capacity}

The ORAC value for the TPC extraction under the most favorable conditions was $490( \pm 54) \mathrm{TE} \mu \mathrm{mol} / \mathrm{LE} \mathrm{g}$. This value is 1.09 and 3.65 times higher than that reported for supercritical extracts of hibiscus (ET $450 \pm 16$ TE $\mu \mathrm{mol} / \mathrm{LE} \mathrm{g}$ ) [47] and green Lavender (ET $134.06 \pm 13.69 \mathrm{TE} \mu \mathrm{mol} / \mathrm{LE} \mathrm{gl}$ [41] respectively. On the other hand, it is noteworthy that this value is only 1.38 and 1.09 times lower than that reported by Martínez [48] for commercial synthetic antioxidants like BHT ( $678 \pm 10$ TE $\mu \mathrm{mol} / \mathrm{LE} \mathrm{g}$ ) and vitamin-E (536 $\pm 8 \mathrm{TE} \mu \mathrm{mol} / \mathrm{g}$ vitamin-E). respectively. These results suggest that cocoa husk (clone $\mathrm{CCN}-51$ ) is a potential source to antioxidant compounds extraction with a high aggregated value using $\mathrm{CO}_{2-s c}$ and ethanol as solvents. 


\section{Conclusions}

The influence of the main parameters of extraction using supercritical $\mathrm{CO}_{2}$ and ethanol in the obtaining of polyphenols and carotenoids from cocoa husk was studied. In that sense, extraction times higher than $120 \mathrm{~min}$ and particle size under $1.105 \mathrm{~mm}$ did not present significant effects on TPC. The conditions evaluated (T: $308.15 ; 313.15$ and $318.15 \mathrm{~K}$; P: $10 ; 15$ and $20 \mathrm{MPa}$ and $\mathrm{X}: 2 ; 11$ and $20 \%$ ) showed that the TPC rises up to $53.84 \%$ with increases in pressure and mass concentration of ethanol. On the other hand, it can be expected that temperature generates reduction in TPC near to $48.28 \%$. A similar behaviour in the variation of flavan-3-ols and total carotenoids content was observed. The supercritical fluid extraction of polyphenols, flavan-3-ols and total carotenoids was described through models that considered the linear and quadratic interaction effects between temperature, pressure and mass concentration of ethanol with an AARD less than $12.20 \%$.

Finally, TPC and antioxidant capacity of the obtained extracts, are comparable to synthetic antioxidants and other compounds obtained from different sources. Consequently, the cocoa husk has the potential to be used as a source of bioactive compounds. This could represent the cocoa husk potential to obtain macronutrients and micronutrients that can be included in the production chain of cocoa. The above represents that the use of this natural resource provides economic and environmental benefits.

\section{References}

[1] J. Jin, Y. Wang, H. Wu, J. Li, and Z. Zhang, "Equilibrium solubilities of ammonium benzoate, benzamide and their mixture in supercritical carbon dioxide," Fluid Phase Equilibria, vol. 334, pp. 152-156, Nov. 2012.

[2] M. Herrero, J. A. Mendiola, A. Cifuentes, and E. Ibáñez, "Supercritical fluid extraction: Recent advances and applications," Journal of Chromatography A, vol. 1217, no. 16, pp. 2495-2511, Apr. 2010.

[3] M. M. de Melo, A. J. Silvestre, and C. M. Silva, "Upercritical fluid extraction of vegetable matrices: Applications, trends and future perspectives of a convincing green technology," The Journal of Supercritical Fluids, vol. 92, pp. 115-176, Aug. 2014.

[4] 0. O. Ortiz, R. A. Villamizar, and J. M. Rangel, "Applying life cycle management of colombian cocoa production," Food Science and Technology (Campinas), vol. 34, no. 1, pp. 62-68, Jan. 2014.

[5] D. P. Galindo and O. J. Barbosa, "Plan De Negocios Aroma \& Sabor Latino," Esp. Tesis, Facultad De Postgrados, Universidad EAN, Bogotá, Colombia, 2013.

[6] M. de agricultura y desarrollo rural, Programa nacional de investigación para incrementar la sostenibilidad y competitividad de la cacaocultura en Colombia, 1st ed. Colombia: Editorial Produmedios, 2010.

[7] L. CristinaVriesmann, R. Dias, and C. L. Oliveira, "Cacao pod husks (theobroma cacao L.): Composition and hot-water-soluble pectins," Industrial Crops and Products, vol. 34, no. 1, pp. 1173-1181, Jul. 2011.

[8] O. B. Smith, E. L. K. Osafo, and A. A. Adegbola, "Studies on the feeding value of agro-industrial by-products: Strategies for improving the utilisation of cocoa-pod-based diets by ruminants," Animal feed science and technology, vol. 20, no. 3, pp. 189-201, Jun. 1988.

[9] S. Y. Chan and W. S. Choo, "Effect of extraction conditions on the yield and chemical properties of pectin from cocoa husks," Food Chemistry, vol. 141, no. 4, pp. 3752-3758, 2013.

[10] J. Serra and M. Aragay, "Composition of dietary fibre in cocoa husk," Zeitschrift für Lebensmitteluntersuchung und-Forschung A, vol. 207, no. 2, pp. 105-109, Aug. 1998.

[11] F. ling and et al, "Alkaline-treated cocoa pod husk as adsorbent for removing methylene blue from aqueous solutions," Journal of Environmental Chemical Engineering, vol. 1, no. 3, pp. 460-465, Sep. 2013.

[12] C. G. Pereira and M. A. Meireles, "Supercritical Fluid Extraction of Bioactive Compounds: Fundamentals, Applications and Economic Perspectives," Food and Bioprocess Technology, vol. 3, no. 3, pp. 340-372, Jun. 2010.

[13] J. L. Martinez, Supercritical Fluid Extraction of Nutraceuticals and Bioactive Compounds, 1st ed. Boca Ratón, Ciudad en Florida: CRC Press, 2007.

[14] M. Quiñones, M. Miguel, and A. Aleixandre, "Los polifenoles, compuestos de origen natural con efectos saludables sobre el sistema cardiovascular," Nutrición Hospitalaria, vol. 27, no. 1, pp. 76-89, 2012.

[15] L. Bravo, "Polyphenols: Chemistry, Dietary Sources, Metabolism, and Nutritional Significance," Nutrition Reviews, vol. 56, no. 11, pp. 317-333, 1998.

[16] M. Harwood, G. Ziegler, and J. Hayes, "Tolerance for high flavanol cocoa powder in semisweet chocolate." Nutrients, vol. 5, no. 6, pp. 2258-2267, Jun. 2013.

[17] D. B. R. and, A guide to carotenoid analysis in foods. United States of America: ILSI Press, 2001.

[18] G. Brunner, Supercritical fluids as solvents and reaction media, 1st ed. Hamburg, Germany: Elsevier Science, 2004.

[19] J. A. et al., "Techniques for extraction of bioactive compounds from plant materials: A review," Journal of Food Engineering, vol. 117, no. 4, pp. 426-436, Aug. 2013.

[20] R. B. Gupta, "Supercritical Fluid Technology for Particle Engineering," in Nanoparticle Technology for Drug Delivery, R. B. Gupta and U. B. Kompella, Eds. Boca Ratón, Florida: CRC Press, 2006, p. 53.

[21] Q. L. and C. M. Wai, "Supercritical fluid extraction in herbal and natural product studies - a practical review," Talanta, vol. 53, no. 4, pp. 771-782, Jan. 2001.

[22] T. C. Kha, H. Phan, and M. H. Nguyen, "Effects of pre-treatments on the yield and carotenoid content of gac oil using supercritical carbon dioxide extraction," Journal of Food Engineering, vol. 120, pp. 44-49, Jan. 2014.

[23] J. I. Boye and Y. Arcand, "Current Trends in Green Technologies in Food Production and Processing," Food Engineering Reviews, vol. 5, no. 1, pp. 1-17, Mar. 2013.

[24] M. L. Zhou, H. F. Wang, and Y. J. He, "Study on supercritical CO-2 fluid extraction technology and properties of carya kernel oil," Food Science, vol. 2, p. 31, 2008.

[25] USDA Database for the Oxygen Radical Absorbance Capacity (ORAC) of Selected Foods, Release 2, U. S. Department of Agriculture (USDA), Beltsville, USA, 2010.

[26] L. J. Sierra and J. D. Peñaranda, “Evaluación de la actividad antioxidante, contenido de polifenoles y metilxantinas en material de cacao de colombia," Undergraduate tesis, Universidad Industrial de Santander, Bucaramanga, Colombia, 2013.

[27] S. Alzamora, S. N. Guerrero, A. B. Nieto, and S. L. Vidales. (2004) Conservación de frutas y hortalizas mediante tecnologías combinadas. Organización de las Naciones Unidas para la Alimentación y la Agricultura. [Online]. Available: http://www.fao.org/3/a-y5771s.pdf

[28] T. Cadena and Y. M. Herrera, “Evaluación del efecto del procesamiento del cacao sobre el contenido de polifenoles y su actividad antixidante," Undergraduate tesis, Fcultad de Ciencias, Universidad Industrial de Santander, Bucaramanga, Colombia, 2008.

[29] C. C. Wang, S. C. Chang, B. Stephen, and B. H. Chen, "Isolation of carotenoids, flavonoids and polysaccharides from lycium barbarum l. and evaluation of antioxidant activity," Food Chemistry, vol. 120, 
no. 1, pp. 184-192, May 2010.

[30] I. X. Cerón, J. C. Higuita, and C. A. Cardona, “Design and analysis of antioxidant compounds from andes berry fruits (rubus glaucus benth) using an enhanced-fluidity liquid extraction process with $\mathrm{CO}_{2}$ and ethanol," The Journal of Supercritical Fluids, vol. 62, pp. 96-101, Feb. 2012.

[31] J. Wollgast and E. Anklam, "Review on polyphenols in Theobroma cacao: changes in composition during the manufacture of chocolate and methodology for identification and quantification," Food Research International, vol. 33, no. 6, pp. 423-447, Jul. 2000.

[32] Y. Nakamura, S. Tsuji, and Y. Tonogai, "Analysis of Proanthocyanidins in Grape Seed Extracts, Health Foods and Grape Seed Oils," Journal of Health Science, vol. 49, no. 1, pp. 45-54, 2003.

[33] S. Matsubara and D. B. Rodriguez, "Teores de catequinas e teaflavinas em chás comercializados no brasil," Ciência e Tecnologia de Alimentos, vol. 26, no. 2, pp. 401-407, 2006.

[34] D. Huang, B. Ou, M. Hampsch, J. A. Flanagan, and R. L. Prior "High-throughput assay of oxygen radical absorbance capacity (ORAC) using a multichannel liquid handling system coupled with a microplate fluorescence reader in 96-well format." J. Agric. Food. Chem., vol. 50, no. 16, pp. 4437-4444, Jul. 2002.

[35] I. Miller, J. Freund, R. A. Johnson, V. González, and F. Rojas, Probabilidad y estadistica para ingenieros, 4th ed. Mexico: Prentice Hall Hispanoamericana, 1992.

[36] N. Niemenak, C. Rohsius, S. Elwers, D. Omokolo, and R. Lieberei, "Comparative study of different cocoa (Theobroma cacao L.) clones in terms of their phenolics and anthocyanins contents," Journal of Food Composition and Analysis, vol. 19, no. 6-7, pp. 612-619, Sep. 2006.

[37] R.Martínez and et al., "Chemical, technological and in vitro antioxidant properties of cocoa (Theobroma cacao L.) co-products," Food Research International, vol. 49, no. 1, pp. 39-45, Nov. 2012.

[38] J. F. A. et al., "Agro-industrial potential of exotic fruit byproducts as a source of food additives," Food Research International, vol. 44, no. 7, pp. 1866-1874, Aug. 2011.

[39] E. Reverchon, "Supercritical fluid extraction and fractionation of essential oils and related products," The Journal of Supercritical
Fluids, vol. 10, no. 1, pp. 1-37, Apr. 1997.

[40] J. M. del Valle and E. L. Uquiche, "Particle size effects on supercritical $\mathrm{CO} 2$ extraction of oil-containing seeds," Journal of the American Oil Chemists' Society, vol. 79, no. 12, pp. 1261-1266, Dec. 2002.

[41] P. Costa and et al., "Supercritical fluid extraction and hydrodistillation for the recovery of bioactive compounds from lavandula viridis l' hér," Food Chemistry, vol. 135, no. 1, pp. 112-121, Nov. 2012.

[42] M. Serhat and E. M. Gürü, "Extraction of oil and B-sitosterol from peach (Prunus persica) seeds using supercritical carbon dioxide," The Journal of Supercritical Fluids, vol. 92, pp. 319-323, Aug. 2014.

[43] F. A. Espinosa, J. Martinez, and H. A. Martinez, "Extraction of bioactive compounds from peach palm pulp (bactris gasipaes) using supercritical $\mathrm{CO}_{2}$," The Journal of Supercritical Fluids, vol. 93, pp. 2-6, Sep. 2014.

[44] I. DöKer, T. I. Stathakis, C. Kazak, K. Karut, and G. T. Papadoulis, "Four new records and two new species of phytoseiidae (Acari: Mesostigmatal from Turkey, with a key to the Turkish species," Zootaxa, vol. 3827, no. 3, Jul. 2014.

[45] M. del P. Garcia, F. A. Cabral, and A. M. H, "Supercritical co2 and pressurized solvents extraction processes for bioactive compounds from mango peel waste (mangifera indica l.)," III Iberoamerican Conference on Supercritical Fluids, Cartagena de Indias, Colombia, 2013.

[46] L. Nasri, S. Bensaad, and Z. Bensetiti, "Correlation and Prediction of the Solubility of Solid Solutes in Chemically Diverse Supercritical Fluids Based on the Expanded Liquid Theory," Advances in Chemical Engineering and Science, vol. 3, no. 4, pp. 255-273, Oct. 2013.

[47] E. Stashenko and et al., "Flower metabolomics: volatile compound profile, antioxidant capacity and lc-ms-tof identification of flavonoids in various tropical flowers," Planta Medica, vol. 81, no. 16, Nov. 2015.

[48] J. R. Martínez, C. Ruiz, G. Arias, and E. Stashenko, "Optimización de la extracción de antioxidantes de salvia officinalis L. con $\mathrm{CO} 2$ supercrítico," Rev. Acad. Colomb. Cienc., vol. 38, no. 148, pp. 237-249, 2014. 